Chirurgia (2020) 115: 551-553

No. 5, September - October

Copyright@ Celsius

\title{
Professor Octavian Dumitru Unc, MD. PhD (1957-2020)
}

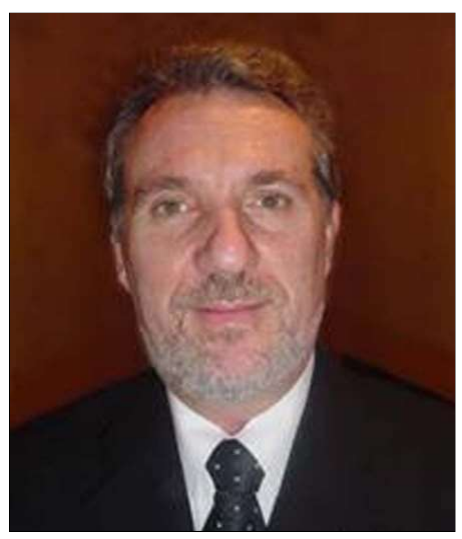

\author{
Vasile Sârbu ${ }^{1,2,3}$, Yusuf Timurlenc ${ }^{1,4}$, Raluca Melihov', Alexandra Doicescu', \\ Silviu Constantinoiu ${ }^{3,5}$
}

${ }^{1}$ University of Ovidius Constanta; ${ }^{2}$ Academy of Scientists of Romania; ${ }^{3}$ Academy of Medical Sciences in Romania

${ }^{4}$ Constanta Emergency Clinical County Hospital

${ }^{5}$ Center of Excellence in Esophageal Surgery, "Sf. Maria" Clinical Hospital

Carol Davila University of Medicine and Pharmacy, Bucharest, Romania

Professor Octavian Unc was one of Dobrogea's most brilliant surgeons and cultural people of the contemporary period. He was not only a surgeon and an exemplary teacher, for he also left behind heritage assets in the field of Dobrogen and national medical literature and historiography. He was born on March 15, 1957, in Zărneşti (Braşov County).

He was a brilliant student of the Ovidius High School in Constanta (then a graduate in 1985 of the Faculty of Medicine in Bucharest) with an average of 9.74 , which was very difficult at the time. He followed the three-year internship in Constanta, then two more years in which he was a district doctor in Cerchezu. He was in Cerchezu when the events of December 1989 took place, and when the Faculty of Medicine and Pharmacy in Constanta was established on March 201990 (the birthday of the poet Ovidius, who also gave the name of the University situated on the bank of the Black Sea). From that moment, which marked a turning point and a historic leap of the medicine of the old Tomis, the young doctor Unc tied his destiny to surgery and the Dobrogean university environment from which he never broke up until the day he passed away.

The young university assistant and resident physician from the year 1990 has carried out his theoretical and practical training in surgery at Coltea Hospital in Bucharest, but especially in the newly established Clinic of Surgery in Constanta. Then he rose through national competitions both in surgery and on the academic line, becoming a primary physician, professor and a $\mathrm{PhD}$ coordinator.

His doctoral thesis drafted in 1999 was entitled "The value of the complex treatment of breast cancer", this area marking the rest of his life. After further training abroad, he became one of the greatest experts in senology in Romania. He performed in all surgical domains, but senology was the domain he was passionate about.

His entire evolution and teaching career took place in a medical institution which represented a nodal point, the triggering point 
of the modern medical bing-bang in Tomis. This was where the first cell of the Faculty of Medicine and Pharmacy in Constanta was located, and the most robust root of Ovidius University.

When the academic medicine of Constanța was a small bundle of cells, an invisible morula, Octavian Unc was one of those cells. This explains his position as a co-author on the first manual printed by the Faculty of Medicine of Constanta, "Elements of Surgical Propedeutics" (V. Sârbu, T. Yusuf, O. Unc).

There were two doctors in this medical institution, who came from the school of surgery of Fundeni, following the steps of professor Dan Setlacec, N. Hortolomei, Toma Ionescu and Constantin Dimitrie Severeanu. The establishment of a surgical school in Constanta, grafted on the emergence of the faculty, led to a new and highly motivated spirit in which Dr Octavian Unc was deeply involved. He fed his spirit directly from Constanța and extracted noble nutrients from Bucharest and Iaşi for many years after he became a specialist surgeon and university professor.

His CV includes numerous additional training and over-specialisation courses. $\mathrm{He}$ learned from great professors of the new European medicine in Marseille (6 months with Professor Argeme-1995), Yokohama (ten days of training in breast cancer surgery- 2000), Badajos (with Professor Tellez and Vingagre), Milano (Breast cancer and reconstruction surgery course), Strasbourg, Verona.

He participated in an impressive number of national courses with guests from abroad, on the subject of varied subjects, like hepatobiliary and pancreatic surgery, bariatric surgery, endoscopic surgery, organ transplantation, laparoscopic hernia surgery.

In 1991, he was part of the group of avantgarde surgeons, and the medical society with the same name, created in Constanta on the occasion of laparoscopic surgery in Romania inauguration.

He then took part in the six-year experimental organ transplant surgeries in 1993, and culminated in the first human renal transplant in Constanța on April 23 1999. He continued with his participation in the introduction of new surgical techniques in the medical institution where he worked: mechanical sutures, eco-guided surgery, transplantation of pancreatic islands and stem cells into diabetes, surgery of the oesophagus, elaboration of anatomical techniques of eye transplantation.

He performed many surgeries for the first time in Dobrogea, such as breast reconstructions after mastectomies for cancers, operations to sanitise overinfected breast cancers, bariatric surgery by enterocolic anastomoses, the use of Sono-surg in breast surgery, the methods of eco guided vascular surgery of hemorrhoidal disease, etc.

He wrote university courses on Surgical Semiology, and was co-author of the "Surgery Emergencies" treaty, published in 1995 at the Bucharest Medical Publishing House. He was also a member of the group of authors of the "Abdominal Surgical Patology", "Thoracic Surgical Pathology" manuals.

He trained 27 series of students and 17 series of resident physicians. Many of the surgeons he formed work around the world. $\mathrm{He}$ was a mentor to more than $30 \mathrm{PhD}$ theses, and he participated in numerous defence committees in Constanta, Bucharest and other university centres.

In 2007, he established the first private surgery clinic in Constanta, where he worked until the end of his life, performing more than 5000 interventions operators. (Medical Analysis Constanta-MACTA).

It is hard to find enough emphasise for the privilege of working together with him in many fields, but I enjoyed a special consideration from him that was mutual. It was not by chance that we wrote together, after an extraordinary effort the "History of Medicine in Dobrogea". We were both directors of the "Victor Gomoiu Magazine of History of Medicine" I drafted in Constanta for five years. He was my right hand at the establishment of the Dobrogeția Cultural Athenaeum, the second Athenaeum in our country, the Romanian Union of Physicians and many other achievements. 
Looking back, I wonder how much I could put on his shoulders and how he carried them all to the end. The collective of surgeons was and will be a very united one, the outstanding achievements containing a part of each one's life. Professor Unc took abroad the message of the achievements of this group of fighters who in thirty years brought great successes to Romanian surgery.

Dr Unc participated in all this labor, in the organisation of the national congresses of Surgery or Transplantology, the congress of the History of Medicine, an area in which he has numerous merits from which we will remember only the rediscovery of a forerunner -Doctor Ervin Bolton, but also the valorisation of Victor Climescu and Dem Teodorescu, about which he was writing a treaty. His merits in surgery, education, history of medicine, have been unanimously recognised, giving him numerous privileged positions at the head of the Surgery Clinic of Constanța, the Constanța Branch of the Romanian Society of Surgery, vice-president of the Romanian Surgery Society, etc. He was a member in the European medical societies such as the French Society of Senology, Europea Digestive Surgery, Balkan Medical Union. He was a member of the Romanian Academy of Scientists, an associate member of CRIFST (Romanian Committee for the History of Science, Philosophy and Technology of the Romanian Academy), and a member of the Romanian Writers' Union. He was co-opted into the management of numerous magazines and collaborated for many years on the "Medical Pages from Bârlad".

His name appears in many dictionaries of great personalities. Being an intellectual, he lectured about Mihai Eminescu and his sufferings, he drafted the "Proper Names in Surgery", he was co-author of "Proper Names in Orthopedics", "A Possible Anthology of Surgeons and Anaesthesiologists Writers", and he wrote "Professor Costache Lazar, the Surgeon".

With an exceptional sensibility and a unique talent for speech and writing, under- standing the subtlety of the Romanian language, he wrote several literary volumes, being received as a member of the Romanian Writers' Union. Time will always rediscover the beauty of his writings, of the verses and the prose. He left as a legacy a novel to be published, his books "Painted verses", "Missing my mother", "The Pontic Ballades", as well as many articles published in numerous magazines, and his unforgettable serial shows on "LitoralTV" in Constanta. All this gives us the image of a colossal man, who was born with the vocation of synthesis, who acquired a remarkable medical and cultural erudition. He will always be an Enlightenment scholar of our century, a man of the citadel, and above all, an unrivalled barometer of morality. He believed and wanted to convince every person that the sun must rise from the Black Sea, before climbing into the highs of the sky over Bucharest and passing the Carpathians to illuminate our immortal Transylvania, the place where his ancestors were born.

His great character, full of medical culture, history, Balkanism, Romanianism, made him loved by many people. He was loved by anyone he met, starting with friends, colleagues, students, writers, clerics, teachers, artists, surgeons from all over the country, numismatists, with the sellers in the antique shops, museums or libraries.

He died on October 24, 2020, killed by the complications of the infection with SARSCOV2 virus, which at the time had caused more than 40 million contaminations and more than a million victims across the planet.

He remains in our memory as a unique doctor in Dobrogea and in Romania, a man who has never negotiated the elements of morality, a vertical man with great sensibility, able to write charming lyrics, to master the scalpel and the pen with perfect craftsmanship, a great believer. He seemed to have a touch of godliness and divine humbleness. He lived intensely every day of his life, not knowing how close he was to the last day, the day that took him from us. He entered the dowry of tears of Romanian surgery. 